\title{
Learning styles of millennial students at a pharmacy school in the Philippines
}

\author{
Darwin I Carrido ${ }^{1,2}$ \& Romeo-Luis F Ramirez ${ }^{1,2}$ \\ ${ }^{1}$ University of the Philippines Manila, Philippines $\quad{ }^{2}$ De La Salle Medical and Health Sciences Institute, Philippines
}

\section{Keywords}

Millennials

Pharmacy Students

Learning Styles

Application-directed Approach

\author{
Correspondence \\ Darwin I Carrido \\ College of Pharmacy \\ University of the Philippines Manila \\ Valenzuela Hall \\ Taft Avenue \\ Ermita \\ Metro Manila \\ Philippines \\ dicarrido@up.edu.ph
}

\begin{abstract}
Background: The millennial generation already composes the majority of populations across different pharmacy schools in the Philippines. The need to explore millennial students' learning styles and its governing factors thereby become more valuable in changing and innovating instructional approaches, designs, and strategies used in their learning environment. Aims: This study aimed to generally describe the learning styles of the millennial pharmacy students from a college institution in the Philippines using the Vermunt's Inventory of Learning Styles (ILS). Specifically, it aimed to determine the appropriate approaches in response to the students' learning styles, and the relationship between and among the variables of the study. Method: A quasiexperimental research design was employed in this study using online survey as the method of data collection. Descriptive statistical analysis was employed to analyse the data using Microsoft Office Excel 2013 and IBM Statistical Package for Social Sciences Statistics. Pearson's correlation coefficient investigated the relationship between and among the independent and dependent variables, while $t$-test and one-way ANOVA tested for significant difference among groups. Results: There were 124 out of 168 students who participated in the study making the overall response rate at $\sim 74 \%$. The most prevalent learning style among the millennial pharmacy students enrolled in De La Salle Medical and Health Sciences Institute, College of Pharmacy is applicationdirected (3.85 \pm 0.46$)$, followed by reproduction-directed (3.81 \pm 0.45$)$, undirected $(3.73 \pm 0.49)$ and lastly meaning-directed (3.52 \pm 0.54$)$. The students' perceived grades were significantly reflected by their learning styles. Conclusion: Results of this study may be used in increased capitalising and development of the learning style profile of millennial pharmacy students to application-directed approaches. Instructional approaches, designs and strategies must cater to how students learn effectively and strategically, and consider all possible governing factors that affect learning styles of students.
\end{abstract}

\section{Introduction}

'Learning style' refers to the organisation and control of the strategies for learning and knowledge acquisition and is configured by the cognitive, affective and personality particularities of the learner (Magdalena, 2015). Much educational research has focused on the concept of learning styles. Several authors have proposed that the ability to typify student learning styles can augment the educational experience. As such, instructors might tailor their teaching style so that it is more congruent with a given student's or class of students' learning style (Romanelli et al., 2009). The current generation of college learners can be viewed as the group between the years of 1982 to 2002 and are often referred to as the millennials (Kotz, 2016). Social researchers suggest that these learners may be different than older generations as a result of aspects of their upbringing (Sickler, 2009). There are no published studies that have systematically examined the learning styles of millennial pharmacy students (Romanelli et al., 2009). 
The millennial generation already composes the majority of populations across different pharmacy schools in the Philippines. Their knowledge of the different learning styles may help improve their academic performance as they learn more about themselves and how to acquire knowledge in the most effective manner, especially in situations where the instructor's teaching style does not match the students' preferred learning style (Choi et al., 2014).

Vermunt's Inventory of Learning Styles (ILS) integrates four components of learning: processing strategies, regulation strategies, mental models of learning, and learning orientations (Vermunt, 1994). He identified four different learning styles: meaning-directed, reproductiondirected, application- directed, and undirected, which displayed characteristic patterns of factor loadings across the four components of learning (Boyle et al., 2003). Students who learn in a meaning-directed way try to understand the meaning of what they learn, discover relations between separate facts or views, structure the learning material into a larger whole, and try to critically engage to what they learn. In reproduction-directed learning, students try to remember the learning content in order to be able to reproduce it in a test. They memorise the learning materials and go through the study materials in a sequential way, step by step, without thinking much about relations between larger units. Students who learn in an application-directed way try to discover relations between what they learn and the world outside. They try to find examples of what they study and think about how they would be able to apply what they learn in practice. Finally, students who learn in an undirected way do not know how to approach their studies. This pattern can often be seen with students who are in transition from one form of schooling to another (Vermunt \& Donche, 2017).

This study would be useful to the development of instructional design and teaching methods among faculty members of the College of Pharmacy, De La Salle Medical and Health Sciences Institute (DLSMHSI), especially considering the newly revised and prescribed policies, standards, and guidelines for the Bachelor of Science in Pharmacy programme. Also, by identifying the governing factors associated with the learning styles of the students, it is particularly useful to facilitate the effective learning of the students, create a conducive learning environment and context, and develop the learning outcomes for the pharmacy students. Therefore, this study aims to generally describe the learning styles of the millennial pharmacy students in DLSMHSI College of Pharmacy using the Vermunt's ILS. The survey consisting of a list of statements on study strategies, motives and attitudes, is used to gain clearer insight into how students go about their studies and how they perceive their own learning (Vermunt, 1994). Specifically, it aims to: 1) assess the learning styles of the pharmacy students at DLSMSHI enrolled in the second semester, academic year 2017-2018; 2) describe the demographic characteristics of the pharmacy students enrolled in DLSMHSI; 3) identify the most prevalent learning style of the students using the Vermunt's ILS and determine the relationship of the student characteristics with the learning style.

\section{Methodology}

A quasi-experimental research design was employed in this study using online survey as the method of data collection. The study population consisted of all the pharmacy students enrolled at DLSMHSI College of Pharmacy, therefore, a one hundred percent (100\%) sampling technique was utilised in the research project. The inclusion criteria included: 1 ) the participants should be officially enrolled in the second semester of the academic year 2017-2018; and 2) must have an age of 25 years and below. Participation in the study was voluntary and the respondents were not rewarded for their cooperation. Participants were given a brief orientation about the project and the informed consent. They were asked to read, comprehend and agree with the consent prior to self-administration of online survey questionnaire. The entire survey took about ten to fifteen minutes to complete. The researchers waited for respondents to complete the survey, and then gave a letter of gratitude to each student who participated. The researchers started collecting data from third week of April 2018 to first week of May 2018. Furthermore, the time and place to conduct data collection was based on the availability and location of the students.

The learning styles were measured by ILS (Vermunt, 1994). The questionnaire comprised of two parts ( $A$ and $B$ ) with a total of 120 statements covering four learning components: cognitive processing strategies, metacognitive regulation strategies, conceptions of learning, and learning orientations. For the strategy items, students were requested to indicate on a 5-point scale the degree to which they use the described learning activities in their studies. The scale varies from ' 1 - I seldom or never do this', to ' 5 - I (almost) always do this'. For the items on learning conceptions and learning orientations, students were asked to indicate on a 5-point scale the degree to which the described views and motives correspond to 
their own views and motives. Here the scale varied from '1-completely disagree' to ' 5 - completely agree'. To identify the learning styles, researchers classified the 120-item questionnaire into four major classifications (meaningdirected, reproduction-directed, application-directed, and undirected).

All research data collected were prepared and encoded in Microsoft Office Excel 2013 for statistical analysis. Each participant who indicated their name was not included for confidentiality purposes. IBM SPSS v.21 was used for correlation and descriptive analysis. Descriptive statistical analysis, measuring the frequency, mean and standard deviation, was employed to describe the different variables in the study. To investigate the relationship between and among independent and dependent variables, Pearson's Correlation Coefficient was used. Independent Samples $t$-test and one-way ANOVA were used to test for significant difference among groups.

\section{Results}

\section{Student Demographic Characteristics}

A total of 124 out of 168 students participated in the study having an overall response rate of $\sim 74 \%$. Majority of the respondents were female and at third year level, while their academic status, whether as regular (students with no failed or incomplete subjects) or irregular (students with failed or incomplete subjects), did not significantly differ (Table I).

\section{Comparison of mean scores of different groups in different learning styles}

There were no significant differences found in the comparison of means between gender, year level, and academic status of students in different learning styles (Table II). However, it can be noted that fourth year level students had higher mean scores in all types of learning style as compared with both second and third year level students

Table I: Student demographic characteristics of DLSMHSI College of Pharmacy

\begin{tabular}{lcc}
\hline Demographics (N=124) & Mean & (SD) \\
\hline Age (Years) & 19.5 & $(1.158)$ \\
GWA (\%) & 81.88 & $(4.34)$ \\
\hline Gender & Overall $\mathbf{n}$ & Percentage (\%) \\
Male & 27 & $(21.8)$ \\
Female & 97 & $(78.2 \%)$ \\
\hline Year Level & & \\
$2^{\text {nd }}$ Year & 13 & $(10.5 \%)$ \\
$3^{\text {rd }}$ Year & 77 & $(62.1 \%)$ \\
$4^{\text {th }}$ Year & 34 & $(27.4 \%)$ \\
\hline Academic Status & & \\
Regular & 65 & $(52.4 \%)$ \\
$\quad$ Irregular & 59 & $(47.6 \%)$ \\
\hline
\end{tabular}

\section{Association of the different factors with learning styles}

Across the learning styles, application- ( $p=0.000, r=0.336)$, meaning- $(p=0.002, r=0.275)$, reproduction-directed ( $p=0.025, r=0.201)$, were found to significantly affect the perceived general weighted average (GWA) of students, while other factors such as age, gender, year level, and academic status of students had no relationship with learning styles (Table III).

\section{Learning styles}

Comparing all the mean scores of different learning styles, application-directed was the most prevalent learning style among the millennial pharmacy students in the DLSMHSI. This was followed by reproduction-directed and undirected learning styles (Table IV).

Table II: Mean scores of different groups in the different learning styles

\begin{tabular}{|c|c|c|c|c|c|c|c|c|c|}
\hline \multirow{2}{*}{$\begin{array}{l}\text { Learning Style } \\
\text { Factors }\end{array}$} & & \multicolumn{2}{|c|}{ Application-Directed } & \multicolumn{2}{|c|}{ Reproduction-Directed } & \multicolumn{2}{|c|}{ Meaning-Directed } & \multicolumn{2}{|c|}{ Undirected } \\
\hline & & Mean & SD & Mean & SD & Mean & SD & Mean & SD \\
\hline Population ( $n=12$ & & 3.85 & 0.46 & 3.81 & 0.45 & 3.52 & 0.54 & 3.73 & 0.49 \\
\hline \multirow{2}{*}{ Gender } & Male & 3.86 & 0.47 & 3.78 & 0.48 & 3.58 & 0.54 & 3.57 & 0.62 \\
\hline & Female & 3.85 & 0.46 & 3.82 & 0.44 & 3.50 & 0.54 & 3.78 & 0.44 \\
\hline \multirow{3}{*}{ Year Level } & $2^{\text {nd }}$ & 3.78 & 0.55 & 3.77 & 0.43 & 3.42 & 0.59 & 3.62 & 0.59 \\
\hline & $3^{\text {rd }}$ & 3.84 & 0.45 & 3.75 & 0.43 & 3.50 & 0.53 & 3.72 & 0.44 \\
\hline & $4^{\text {th }}$ & 3.89 & 0.46 & 3.81 & 0.46 & 3.59 & 0.56 & 3.81 & 0.56 \\
\hline \multirow{2}{*}{ Academic Status } & Regular & 3.88 & 0.47 & 3.79 & 0.45 & 3.81 & 0.56 & 3.67 & 3.81 \\
\hline & Irregular & 3.83 & 0.45 & 3.83 & 0.45 & 3.53 & 0.52 & 0.48 & 0.49 \\
\hline
\end{tabular}


Table III: Correlation between independent variables and learning styles

\begin{tabular}{|c|c|c|c|c|c|}
\hline Factors & Learning Styles & Application-Directed & Reproduction-Directed & Meaning-Directed & Undirected \\
\hline \multirow[t]{2}{*}{ Age } & Pearson Correlation & -0.044 & -0.056 & -0.105 & -0.163 \\
\hline & Sig. (2-tailed) & 0.628 & 0.540 & 0.246 & 0.070 \\
\hline \multirow[t]{2}{*}{ GWA } & Pearson Correlation & $0.336^{* *}$ & $0.201^{*}$ & $0.275^{* *}$ & -0.105 \\
\hline & Sig. (2-tailed) & 0.000 & 0.025 & 0.002 & 0.246 \\
\hline \multirow[t]{2}{*}{ Gender } & Pearson Correlation & 0.010 & -0.032 & 0.057 & -0.175 \\
\hline & Sig. (2-tailed) & 0.914 & 0.726 & 0.530 & 0.052 \\
\hline \multirow[t]{2}{*}{ Year Level } & Pearson Correlation & 0.067 & $0.178^{*}$ & 0.095 & 0.118 \\
\hline & Sig. (2-tailed) & 0.456 & 0.048 & 0.292 & 0.194 \\
\hline \multirow[t]{2}{*}{ Academic Status } & Pearson Correlation & -0.056 & 0.048 & -0.023 & 0.145 \\
\hline & Sig. (2-tailed) & 0.540 & 0.595 & 0.801 & 0.108 \\
\hline
\end{tabular}

Table IV: Mean scores of the respondents on the Vermunt's ILS with classification of different learning styles

\begin{tabular}{|c|c|c|}
\hline Study Activities & Mean & SD \\
\hline 1. To test my own progress, I try to describe the content of a paragraph in my own words. & 3.84 & 0.923 \\
\hline 2. I use the instructions and the course objectives given by the teacher to know exactly what to do. & 3.81 & 0.940 \\
\hline 3. I pay particular attention to facts, concepts and problem solving methods in a course. & 3.81 & 0.960 \\
\hline 4. I pay particular attention to those parts of a course that have practical utility. & 3.77 & 0.818 \\
\hline 5. I study according to the instructions given in the study materials or provided by the teacher. & 3.76 & 0.957 \\
\hline 6. I make a list of the most important facts and learn them by heart. & 3.75 & 1.017 \\
\hline $\begin{array}{l}\text { 7. I experience the introductions, objectives, instructions, assignments and test items given by the teacher as indispensable guidelines } \\
\text { for my studies. }\end{array}$ & 3.75 & 1.025 \\
\hline $\begin{array}{l}\text { 8. If I am able to complete all the assignments given in the study materials or by the teacher, I decide that I have a good command of } \\
\text { the subject matter. }\end{array}$ & 3.73 & 0.999 \\
\hline 9. To test my learning progress when I have studied a textbook, I try to formulate the main points in my own words. & 3.70 & 1.036 \\
\hline 10. When I start reading a new chapter or article, I first think about the best way to study it. & 3.70 & 1.097 \\
\hline 11. When I have difficulty grasping a particular piece of subject matter, I try to analyse why it is difficult for me. & 3.68 & 0.967 \\
\hline 12. I try to construct an overall picture of a course for myself. & 3.65 & 1.067 \\
\hline 13. When I am studying a topic, I think of cases I know from my own experience that are connected to that topic. & 3.65 & 1.075 \\
\hline 14. I try to discover the similarities and differences between the theories that are dealt within the course. & 3.60 & 0.994 \\
\hline 15. I try to see the connection between the topics discussed in different chapters of a textbook. & 3.60 & 1.103 \\
\hline 16. I study the subject matter in the same sequence as it is dealt with in the course. & 3.56 & 1.061 \\
\hline 17. When doing assignments, I train myself thoroughly in applying the methods dealt with in a course. & 3.56 & 0.913 \\
\hline 18. I memorize lists of characteristics of a certain phenomenon. & 3.53 & 1.063 \\
\hline 19. I notice that I have trouble processing a large amount of subject matter. & 3.52 & 1.000 \\
\hline 20. I try to relate new subject matter to knowledge I already have about the topic concerned. & 3.51 & 0.967 \\
\hline 21. I use what I learn from a course in my activities outside my studies. & 3.50 & 1.078 \\
\hline 22. If I do not understand a study text well, I try to find other literature about the subject concerned. & 3.49 & 1.115 \\
\hline 23. I study details thoroughly. & 3.48 & 0.992 \\
\hline 24. I memorise the meaning of every concept that is unfamiliar to me. & 3.46 & 1.070 \\
\hline 25. I repeat the main parts of the subject matter until I know them by heart. & 3.42 & 1.045 \\
\hline 26. When I am studying, I also pursue learning goals that have not been set by the teacher but by myself. & 3.41 & 1.155 \\
\hline 27. I do not proceed to a subsequent chapter until I have mastered the current chapter in detail. & 3.39 & 1.087 \\
\hline 28. I test my learning progress solely by completing the questions, tasks and exercises provided by the teacher or the textbook. & 3.38 & 1.064 \\
\hline 29. I memorize definitions as literally as possible & 3.36 & 1.232 \\
\hline $\begin{array}{l}\text { 30. To test whether I have mastered the subject matter, I try to think up other examples and problems besides the ones given in the } \\
\text { study materials or by the teacher. }\end{array}$ & 3.36 & 1.099 \\
\hline 31. I relate specific facts to the main issue in a chapter or article. & 3.35 & 1.060 \\
\hline 32. I try to interpret events in everyday reality with the help of the knowledge I have acquired in a course. & 3.34 & 1.089 \\
\hline 33. I study all the subject matter in the same way. & 3.31 & 1.062 \\
\hline 34. I notice that it is difficult for me to determine whether I have mastered the subject matter sufficiently. & 3.27 & 1.085 \\
\hline 35. I analyse the successive steps in an argumentation one by one. & 3.27 & 0.955 \\
\hline 36. With the help of the theories presented in a course, I devise solutions to practical problems. & 3.26 & 0.978 \\
\hline 37. I analyze the separate components of a theory step by step. & 3.25 & 1.009 \\
\hline 38. I draw my own conclusions on the basis of the data that are presented in a course. & 3.18 & 1.075 \\
\hline 39. I compare the conclusions drawn in different chapters. & 3.17 & 1.010 \\
\hline
\end{tabular}


Table IV: Mean scores of the respondents on the Vermunt's ILS with classification of different learning styles (continued)

\begin{tabular}{|c|c|c|}
\hline Study Activities & Mean & SD \\
\hline 40. I try to be critical of the interpretations of experts. & 3.15 & 0.955 \\
\hline 41. I realise that I miss someone to fall back on in case of difficulties. & 3.13 & 1.059 \\
\hline $\begin{array}{l}\text { 42. If I am able to give a good answer to the questions posed in the textbook or by the teacher, I decide that I have a good command of } \\
\text { the subject matter. }\end{array}$ & 3.11 & 1.098 \\
\hline 43. I try to combine the subjects that are dealt with separately in a course into one whole. & 3.10 & 1.174 \\
\hline 44. I realise that it is not clear to me what I have to remember and what I do not have to remember. & 3.10 & 1.146 \\
\hline 45. To test my learning progress, I try to answer questions about the subject matter which I make up myself. & 3.10 & 1.073 \\
\hline 46. I learn everything exactly as I find it in the textbooks. & 3.08 & 0.993 \\
\hline 47. I add something to the subject matter from other sources. & 3.05 & 1.096 \\
\hline 48. I check whether the conclusions drawn by the authors of a textbook follow the facts on which they are based logically. & 2.97 & 1.066 \\
\hline 49. If a textbook contains questions or assignments, I work them out completely as soon as I come across them while studying. & 2.90 & 1.110 \\
\hline 50. I work through a chapter in a textbook item by item and I study each part separately. & 2.78 & 1.032 \\
\hline 51. I do more than I am expected to do in a course. & 2.73 & 0.966 \\
\hline 52. I realise that the objectives of the course are too general for me to offer any support. & 2.69 & 1.107 \\
\hline 53. In addition to the syllabus, I study other literature related to the content of the course. & 2.68 & 1.017 \\
\hline 54. I compare my view of a course topic with the views of the authors of the textbook used in that course. & 2.49 & 1.078 \\
\hline 55. I notice that the study instructions that are given are not very clear to me. & 2.46 & 0.966 \\
\hline Study Motives [1] & Mean & SD \\
\hline 56. I want to discover my own qualities, the things I am capable and incapable of. & 4.65 & 0.627 \\
\hline 57. The main goal I pursue in my studies is to prepare myself for a profession. & 4.52 & 0.715 \\
\hline 58. I want to prove to myself that I am capable of doing studies in higher education. & 4.44 & 0.779 \\
\hline 59. When I have a choice, I opt for courses that seem useful to me for my present or future profession. & 4.29 & 0.609 \\
\hline 60. I want to show others that I am capable of successfully doing a higher education programme. & 4.23 & 0.912 \\
\hline 61. I view the choice I have made to enrol in higher education as a challenge. & 4.10 & 0.863 \\
\hline 62. For the kind of work I would like to do, I need to have studied in higher education. & 4.08 & 0.951 \\
\hline 63. I aim at attaining high levels of study achievements. & 4.03 & 0.881 \\
\hline 64. I have chosen this subject area, because it prepares me for the type of work I am highly interested in. & 3.97 & 0.979 \\
\hline 65. I do these studies out of sheer interest in the topics that are dealt with. & 3.85 & 0.803 \\
\hline 66. I study above all to pass the exam. & 3.81 & 0.899 \\
\hline 67. The only aim of my studies is to enrich myself. & 3.73 & 0.947 \\
\hline 68. What I want in these studies is to earn credits for a diploma. & 3.72 & 1.040 \\
\hline 69. The main goal I pursue in my studies is to pass exams. & 3.56 & 1.205 \\
\hline 70. I have little confidence in my study capacities. 70 & 3.53 & 1.172 \\
\hline 71. I doubt whether this is the right subject area for me. & 3.08 & 1.076 \\
\hline 72. I see these studies as sheer relaxation. & 2.78 & 1.086 \\
\hline 73. What I want to acquire above all through my studies is professional skill. & 4.34 & 0.873 \\
\hline 74. When I have a choice, I opt for courses that suit my personal interests. & 4.16 & 0.932 \\
\hline 75. I want to test myself to see whether I am capable of doing studies in higher education. & 4.05 & 1.035 \\
\hline 76. I do these studies because I like to learn and to study. & 4.01 & 0.950 \\
\hline 77. To me, written proof of having passed an exam represents something of value in itself. & 3.75 & 1.131 \\
\hline 78. I wonder whether these studies are worth all the effort. & 3.40 & 1.268 \\
\hline 79. I doubt whether this type of education is the right type of education for me. & 3.01 & 1.328 \\
\hline 80. I am afraid these studies are too demanding for me. & 2.98 & 1.288 \\
\hline 81. To me, learning means acquiring knowledge and skills that I can later apply in practice. & 4.67 & 0.506 \\
\hline 82. To me, learning means acquiring knowledge that I can use in everyday life. & 4.65 & 0.542 \\
\hline 83. To me, learning is providing myself with information that I can use immediately or in the longer term. & 4.62 & 0.504 \\
\hline 84. The teacher should inspire me to work out how the course material relates to reality. & 4.48 & 0.727 \\
\hline 85. The teacher should motivate and encourage me. & 4.45 & 0.714 \\
\hline 86. In order to learn, I have to summarise in my own words what the subject matter means. & 4.44 & 0.678 \\
\hline 87. In order to check whether I have mastered the subject matter, I should try to describe the main points in my own words. & 4.42 & 0.664 \\
\hline 88. The things I learn have to be useful for solving practical problems. 88 & 4.40 & 0.582 \\
\hline 89. I like to be given precise instructions as to how to go about solving a task or doing an assignment. & 4.40 & 0.624 \\
\hline $\begin{array}{l}\text { 90. To me, learning means trying to approach a problem from many different angles, including aspects that were previously unknown to } \\
\text { me. }\end{array}$ & 4.39 & 0.659 \\
\hline 91. I should try myself to apply the theories dealt with in a course to practical situations. & 4.38 & 0.593 \\
\hline 92. I think good teaching is teaching that includes some preparation on my own part. & 4.38 & 0.658 \\
\hline
\end{tabular}


Table IV: Mean scores of the respondents on the Vermunt's ILS with classification of different learning styles (continued)

\begin{tabular}{|c|c|c|}
\hline Study Activities & Mean & SD \\
\hline 93. To me, learning is making sure that I can reproduce the facts presented in a course. & 4.36 & 0.691 \\
\hline 94. The teacher should explain clearly what is important and what is less important for me to know. & 4.32 & 0.812 \\
\hline 95. The teacher should give trial tests to enable me to check whether I have mastered all of the subject matter. & 4.27 & 0.714 \\
\hline 96. I consider it important to discuss the subject matter with other students. & 4.26 & 0.753 \\
\hline 97. If I have difficulty understanding a particular topic, I should consult other books of my own accord. & 4.24 & 0.820 \\
\hline 98. To test my own learning progress, I should try to answer questions about the subject matter which I make up myself. & 4.21 & 0.829 \\
\hline 99. The teacher should encourage me to combine the separate components of a course into a whole. & 4.19 & 0.779 \\
\hline 100. I should repeat the subject matter on my own until I know it sufficiently. & 4.19 & 0.862 \\
\hline 101. I should look for relationships within the subject matter of my own accord. & 4.18 & 0.744 \\
\hline 102. When I have difficulty understanding particular topics, I prefer to ask other students for help. & 4.18 & 0.902 \\
\hline 103. The teacher should encourage me to check myself whether I have mastered the subject matter. & 4.16 & 0.810 \\
\hline 104. The teacher should encourage me to reflect on the way I study and how to develop my way of studying. & 4.16 & 0.810 \\
\hline 105. Good teaching includes giving a lot of questions and exercises to test whether I have mastered the subject matter. & 4.15 & 0.952 \\
\hline 106. I think it is important to check with other students to see whether I have sufficiently understood the subject matter. & 4.12 & 0.728 \\
\hline 107. To me, learning means: trying to remember the subject matter I am given. & 4.07 & 0.885 \\
\hline 108. I should try to think up examples with the study materials of my own accord. & 4.07 & 0.876 \\
\hline 109. I should memorise definitions and other facts on my own. & 4.06 & 0.834 \\
\hline 110. I have a preference for courses in which a lot of practical applications of the theoretical parts are given. & 4.05 & 0.661 \\
\hline 111. I like to be encouraged by other students to process the study materials at a particular pace. & 4.04 & 1.031 \\
\hline $\begin{array}{l}\text { 112. I think I cannot just rely on the books recommended by the syllabus, so I have to try to discover myself what else has been written } \\
\text { about a particular course topic. }\end{array}$ & 4.00 & 0.954 \\
\hline 113. The teacher should encourage me to compare the various theories that are dealt with in a course. & 3.99 & 0.841 \\
\hline 114. I prefer a type of instruction in which I am told exactly what I need to know for an exam. & 3.91 & 1.012 \\
\hline 115. I consider it important to be advised by other students as to how to approach my studies. & 3.88 & 1.033 \\
\hline 116. When I have difficulties, the teacher should encourage me to find out for myself what causes them. & 3.86 & 0.957 \\
\hline 117. I have a need to work together with other students in my studies. & 3.71 & 1.153 \\
\hline 118. I prefer to do assignments together with other students. & 3.70 & 1.004 \\
\hline 119. When I have difficulty understanding something, the teacher should encourage me to find a solution by myself. & 3.69 & 0.974 \\
\hline 120. When I prepare myself for an exam, I prefer to do so together with other students. & 3.30 & 1.196 \\
\hline
\end{tabular}

\section{Discussion}

Vermunt (1994) distinguishes four different learning styles: application-directed, reproduction-directed, meaning-directed, and undirected learning style. What distinguishes Vermunt's learning styles from other models is that it was developed as a diagnostic tool for use in a higher education context. As the survey participants were already in tertiary education, Vermunt's questionnaire was utilised and applied. Students with an applicationdirected learning style try to employ what they learn to actual, real-world settings (Busato et al., 1998). The high mean score of the respondents in this type of learning style (3.850.46) may be attributed to the pharmacy curriculum of the DLSMHSI College of Pharmacy since their internships in community, hospital, and manufacturing pharmacy are incorporated in the curriculum wherein students are simultaneously taking their experiential education along with their subjects from the school. For instance, third year level students are undergoing internship in the manufacturing setting while fourth years are taking their major internship in hospital pharmacy practice. Their exposure to the real-world setting might have contributed to their scores. The curriculum design, which placed the internship towards the end as a platform for integration, may suggest why students had higher means for application-directed learning style. This may have resulted in lower mean scores for the other learning styles, reproduction-directed $(3.81 \pm 0.45)$ that primarily reflects cognitive recall, undirected $(3.73 \pm 0.49)$ that follows no pattern, and meaning-directed $(3.52 \pm 0.54)$ that engages in higher order of thinking than recall. These were the learning styles that were described for the survey participants, the millennial students.

Although literature suggests that academic performance has little influence on the learning styles of students (Vermunt, 2005; Wilkinson et al., 2013; Choi \& Yu, 2014), this study found that perceived grades of students had positive correlation with all types of learning styles, except undirected with negative correlation. Students characterised by an undirected learning style had, for example, problems with processing material for study, experience difficulties with the amount of study material, 
and with discriminating what is important and what is not although this result was not significant. On the other hand, the result of this study is consistent with the study conducted by Busato et al. (1998), which revealed that positive correlations were found for achievement motivation with the meaning-, reproduction- and the application-directed learning style, and a negative one with the undirected learning style. It may be presumed that millennial students motivated to study effectively using these learning styles have better academic performance.

Being part of the millennial generation, age had no relationship with the learning styles of the students. This is consistent with the study conducted by Vermunt (2005) where age showed little associations with the learning patterns of the student participants, specifically the reproduction-directed, application-directed, and undirected learning. They more often consult other sources than the prescribed syllabus, think that learning is equivalent to constructing their own knowledge and insights, use both deep processing strategies, study out of personal interest, and use a self-regulation strategy directed at their learning process and results, than younger students. However, Vermunt (2005) stated that age is an important predictor of meaning-directed learning. Learning is affected by factors such as the learning environment, interest in the material under study, and learning style preferences (Choi et al., 2014). The ideal learning environment is one that promotes students' motivation to master and acquire a deep understanding of the course material, and that develops self-directed and independent study skills. This mastery approach in learning is essential for the acquisition of critical-thinking and problem-solving skills and for fostering a desire for the lifelong learning attributes that are preferred in students of the healthcare profession. These approaches to learning are also believed to lead to enhanced academic performance (Choi et al., 2014). Moreover, according to these authors, there was no significant relationship found between learning style and academic performance. Each learning style favours a certain teaching method, but there was no relationship found between learning style and academic performance. The learning style profile of the students may be built upon, to develop meaning-directed approaches by focusing on interventions that will promote deep, critical processing and self-regulation.

Other authors have proposed correlations between culture and learning styles (Romanelli et al., 2009). This is based on the concept that culture influences environmental perceptions which may determine the way in which information is processed and organised. Technology may also be influencing the learning styles of younger students and emerging generations of learners. The millennials have been described as more technologically-advanced with higher expectations for the use of computer-aided media in the classroom (Romanelli et al., 2009). In pharmacy education, electronic learning or e-learning effectively increases knowledge and is a highly acceptable instructional format for pharmacists and pharmacy students. However, there is limited evidence that e-learning effectively improves skills or professional practice. There is also no evidence that e-learning is effective at increasing knowledge long term; thus, longterm follow-up studies are required (Salter et al., 2014).

The study reported by Djiwandono (2017), on the other hand, revealed that there was no significant correlation between the learning styles of students and their achievements in language and content course, but found that there was a modest correlation between the amount of verbal report and their ultimate mastery of the course content. He attributed this result to the instructional context and cultural aspects that shaped the respondents' learning styles (Djiwandono, 2017). However, this study has included 22 learners in their twenties. Certainly, a larger sample could be used to yield more information and better assessment of learning. Magdalena (2015), found significant differences with regards to the learning style and learning behaviour, according to the age, experience, and academic performance type. Their study reported that there were significant associations between learning style and learning strategies and suggested that future studies be developed to determine the predictive relationship between learning style and learning strategy. Moreover, in terms of the relationship between learning style and academic performance, metacognitive performance was associated with the theoretical and practical engagement of students with work experience, and deep learning strategy was found to be associated with high performance in the theoretical activities in students who did not have professional experience. Prediction and improvement of academic success represent a current issue in the field of academic learning. Finding the factors which influence academic success has strong implications on research in the learning field, on educational policies, and implicitly on students' learning strategies (Magdalena, 2015).

Similar to the study conducted by Novak et al. (2006), a major limitation also considered was that the teaching styles of the students' instructors were not directly measured. This is because Vermunt's ILS was designed to be answered by students only. Therefore, further research was planned by the researchers to also examine 
the effect of the instructor's teaching style, and how it affects students' learning style. In addition to examining the instructor's teaching style, the students' personality types may also be explored and related to their learning style. While it is beyond the scope of Vermunt's ILS questionnaire, Myers-Briggs Type Indicator (MBTI) personality types were found to be relevant in describing the students' learning styles (Shuck \& Phillips, 1999). Williams et al. (2013) also incorporated the relevance of MBTI personality types on students' learning styles in their study, supporting the need to determine the learning styles of students to facilitate the instructional design of instructors, who are in this case, facilitating the learning of millennial students.

\section{Conclusion}

The most prevalent learning style among the millennial pharmacy students enrolled in DLSMHSI College of Pharmacy is application-directed, followed by reproductiondirected and undirected, and lastly meaning-directed. No significant relationship was found between learning style and age, gender, year level, or academic status, but a significant relationship was found with the GWA or academic performance of the students. Results of this study may be used in capitalising and further developing the learning style profile of the millennial pharmacy students to application-directed approaches. Instructional approaches, designs and strategies must cater to how students learn effectively and strategically, and consider all possible governing factors that affect the learning styles of students.

\section{References}

Boyle, E.A., Duffy, T., \& Dunleavy, K. (2003). Learning styles and academic outcome: the validity and utility of Vermunt's Inventory of Learning Styles in a British higher education setting. British Journal of Educational Psychology, 73(2), 267-90. https://doi.org/ $\underline{10.1348 / 00070990360626976}$

Busato, V.V., Prins, F.J., Elshout, J.J., \& Hamaker, C. 1998. The relation between learning styles, the Big Five personality traits and achievement motivation in higher education. Personality and Individual Differences, 26(1), 126-140. https://doi.org/10.1016/ $\underline{\text { S0191-8869(98)00112-3 }}$

Choi, F., Yu. A., \& Loquias, M. (2014). Learning Styles of Pharmacy Students in the University of the Philippines - Manila (UP Manila). International Journal of Pharmacy Teaching \& Practices, 5(2),949-955

Crawford, S.Y., \& Popovich, N. (2012). Comparison of Learning Styles of Pharmacy Students and Faculty Members. American Journal of Pharmaceutical Education, 76(10), 92. https://doi.org/ 10.5688/ajpe7610192
Djiwandono, P.I. (2017). The Learning Styles of Millennial Generation in University: A Study in Indonesian Context. International Journal of Education, 10(1), 12-19. https://doi.org/ $\underline{10.17509 / \text { ije.v10i1.5085 }}$

Kotz, P.E. (2016). Reaching the millennial generation in the classroom. Universal Journal of Educational Research, 4(5), 1163-1166. https://doi.org/10.13189/ujer.2016.040528.

Magdalena, S.M. (2015). The relationship of learning styles, learning behaviour and learning outcomes at the Romanian students. Procendia - Social and Behavioural Sciences, 180, 1667-1672. https://doi.org/10.1016/j.sbspro.2015.05.062

Nicholas, A. (2008). Preferred Learning Methods of the Millennial Generation. Faculty and Staff - Articles \& Papers, 18. https:// doi.org/10.18848/1447-9494/CGP/v15i06/45805

Novak, S., Shah, S., Wilson, J.P., Lawson, K.A., \& Salzman R.D. (2006). Pharmacy students' learning styles before and after a problem-based learning experience. American Journal of Pharmaceutical Education, 70(4), 74 https://doi.org/10.5688/aj $\underline{700474}$

Romanelli, F., Bird, E., \& Ryan, M. (2009). Learning Styles: A Review of Theory, Application, and Best Practices. American Journal of Pharmaceutical Education, 72(1), 9. https://doi.org/ $\underline{10.5688 / a j 730109}$

Salter, S.M., Karia, A., Sanfilippo, F.M., \& Clifford, R.M. (2014). Effectiveness of E-Learning in Pharmacy Education. American Journal of Pharmaceutical Education, 78(4), 83. https://doi.org/ $\underline{10.5688 / a j p e 78483}$

Shuck, A.A., \& Phillips, C.R. (1999). Assessing Pharmacy Students' Learning Styles and Personability Types: A Ten-Year Analysis. American Journal of Pharmaceutical Education, 63(1)

Sickler, S.M. (2009). A Study of Millennial Student Learning Preferences: An Analysis of Two Interior Design Class Case Studies. Florida state University. FSU Digital Library. Available at: https:// diginole.lib.fsu.edu/islandora/object/fsu\%3A176230

Vermunt, J. D. (1994). Inventory of Learning styles (ILS) in Higher Education. Tilburg, The Netherlands: Tilburg University, Department of Educational Psychology

Vermunt, J.D. (2005). Relations between student learning patterns and personal and contextual factors and academic performance. Higher Education, 49, 205. https://doi.org/10.1007/ s10734-004-6664-2

Vermunt, J.D., \& Donche, V.A. (2017). Learning Patterns Perspective on Student Learning in Higher Education: State of the Art and Moving Forward. Educational Psychology Review, 29, 269-299. https://doi.org/10.1007/s10648-017-9414-6

Wilkinson, T., Boohan, M., \& Stevenson, M. (2014). Does learning style influence academic performance in different forms of assessment? Journal of Anatomy, 224, 304-308. https://doi.org/ $\underline{10.1111 / \text { joa.12126 }}$

Williams, B., Brown, T., \& Etherington, J. (2013). Learning style preferences of undergraduate pharmacy students. Currents in Pharmacy Teaching and Learning, 5(2), 110-119. https://doi.org/ 10.1016/j.cptl.2012.09.003 